\title{
DOS USOS COMUNITÁRIOS DA WEBRADIOFONIA NO CONTEXTO MIGRATÓRIO TRANSNACIONAL
}

\author{
Mohammed Elhajji ${ }^{1}$ \\ João Paulo Malerba²
}

O fenômeno migratório experimenta, na atualidade, excepcional intensificação. Além das causas sociais, econômicas e políticas, contribuem fatores tecnológicos e simbólico-subjetivos. O desejo e a necessidade de produção de narrativas próprias, que auxiliem na manutenção dos vínculos do migrante para com a comunidade de origem e de diáspora, encontram amparo em recursos midiáticos inovadores, agrupados sob a noção de 'webdiáspora'. Dentre eles, destacamos as webrádios comunitárias dos grupos migrantes - objeto do presente estudo, no afã de apreender algumas das modalidades de organização das comunidades migrantes, suas estratégias de conquista de cidadania global e de atuação nos espaços transnacionais. Tendo como baliza o estudo de caso de webrádios de comunidades migrantes, buscamos evidenciar as potencialidades e os limites da webdiáspora para a democratização dos meios e os desafios teóricos e conceituais que tais mudanças representam para os estudos de comunicação comunitária.

Palavras-chave: migrações transnacionais, Webrádios comunitárias, comunicação comunitária, TICs.

\section{Migrantes}

As migrações são constitutivas da experiência civilizacional e até existencial da espécie humana: não somos migrantes por opção, mas sim por natureza. A própria epopeia humana iniciou-se no impulso de ampliar seus horizontes espaciais e mentais, multiplicar suas possibilidades de vencer as adversidades do espaço e do tempo e dar forma e sentido à sua jornada real e imaginada ${ }^{3}$.

Programa de Pós-Graduação em Comunicação da UFRJ. Rio de Janeiro, RJ, Brasil.

2 Doutorando em Comunicação e Cultura pela UFRJ. Rio de Janeiro, RJ, Brasil.

3 ELHAJJI, Mohammed. Mapas subjetivos de um mundo em movimento: migrações, mídia étnica e identidades transnacionais. 
Migrações, transumâncias, peregrinações, mobilidade em geral e deslocamentos de todo tipo refletem a propensão humana em conhecer, descobrir, ir ao encontro do desconhecido, compartilhar com o diferente... comunicar, em suma. Mas, se desde as origens da sociedade humana não há como dissociar o fato migratório do ato comunicativo, com a chegada da modernidade a relação já íntima se tornou francamente simbiótica. Sendo a noção de comunicação aqui entendida em suas acepções materiais e simbólicas: meios de transporte, de aceleração da produção, de controle social e de difusão e troca de ideias.

Trata-se de uma reconfiguração radical que não poupou nenhum dos aspectos da vida em sociedade, nos planos locais, regionais, nacionais e globais. Além das consequências sociais, terá também efeitos de ordem subjetiva e psicológica sobre o indivíduo moderno, ampliando sua capacidade autorreflexiva e reforçando sua vontade de liberdade e autonomia.

No nível macrossociológico, os séculos XIX e XX registraram contínuos deslocamentos populacionais rumo ao centro e às regiões mais ricas do planeta. As migrações humanas chegaram ao seu ápice, entrando numa fase de planejamento e administração verdadeiramente industriais, espelhando as técnicas de produção em massa, os ideais do fordismo e dos meios de comunicação de massa.

Porém, é no plano micro e molecular e/ou a partir de perspectivas sociológicas de proximidade que se pode realmente acessar os registros subjetivos do fenômeno - aqueles que traduzem com maior fidelidade a realidade e vivência imediata do ator principal do fato migratório: o migrante.

Mas o que é um migrante? Não há dúvida que a essência do sujeito migrante reside, antes de tudo, na sua estrangeiridade. Além da constatação jurídica que define a situação legal do imigrante a partir de sua condição negativa de não nacional, há de se concordar que são a diferença, a alteridade e a externalidade do forasteiro que servem de indicadores e parâmetros para situá-lo e lhe dar sentido aos olhos da sociedade na qual se encontra e dos grupos majoritários e/ou hegemônicos que o cercam: o estrangeiro é "o exterior e contrário" da sociedade e grupos dominantes ${ }^{4}$.

O migrante se revela, então, um perfeito reflexo diferencial da maioria e 'normalidade'; um catalisador da diferença da/na estrangeiridade e da própria diferença, até então despercebida, daqueles que se colocam ou se veem como norma e medida. A presença do estrangeiro tem, pois, esse potencial de provocar no observador estranheza e estranhamento; seja de modo positivo: maravilhamento e fascínio, ou negativo: repulsa e medo.

A estrangeiridade, enquanto signo e sintoma, tem o mérito de anular as fantasias de absolutismo e indiferença do sujeito central e nele insuflar o germe do relativismo crítico: "a diferença desse rosto revela um paroxismo que qualquer

4 SIMMEL, Georg. O estrangeiro, p. 265. 
rosto deveria revelar ao olhar atento: a inexistência da banalidade entre os seres humanos" ${ }^{\prime \prime}$. Do amor ao ódio, a presença do estrangeiro nos obriga a mostrar a nossa verdadeira natureza e revelar nosso modo verdadeiro de encarar o mundo.

\section{Minorias}

Em regra geral, os migrantes são minoritários; quantitativamente menores com relação aos grupos nacionais, étnicos ou culturais que dominam numérica e politicamente a sociedade de acolhimento. Debilidade ou precariedade quantitativa que resulta, muitas vezes, em condição e/ou estatuto social e político de subalternidade. O que, não raramente, resulta em diversas formas de discriminação, racismo, xenofobia, opressão ou estigmatização do grupo minoritário e seus membros.

As minorias, segundo Appadurai ${ }^{6}$, são uma categoria social e demográfica recente, "essencialmente vinculadas a ideias sobre nação, população, representação e enumeração, que não têm mais de que alguns séculos de idade" e se deve ao aprimoramento contemporâneo das "técnicas de contar e classificar e de participação política" intrínsecas à época moderna7. A figura minoritária do migrante corresponde, de certo modo, à noção de "pequeno número", proposta por Appadurai e que se refere a formas contemporâneas de negativação simbólica de grupos indesejados da sociedade, a fim de positivar a totalidade da comunidade.

Mas, a "pequenez" do número não se reduz ao seu aspecto formal, quantitativo e concreto. A minoria, segundo Sodré ${ }^{8}$, se caracteriza, dentre outros aspectos, por sua vulnerabilidade jurídico-social, na medida em que o grupo minoritário, tal como é o caso dos migrantes, "não é institucionalizado pelas regras do ordenamento jurídico-social vigente" ${ }^{\prime \prime}$. Do ponto de vista jurídico, o termo estrangeiro designa o indivíduo ou conjunto de indivíduos que, embora estejam vivendo num determinado Estado, "não pertencem ao círculo daquelas pessoas que possuem a nacionalidade desse Estado". Trata-se, portanto, de um referencial negativo ${ }^{10}$.

O estatuto jurídico e social excepcional do migrante é apontado por Sayad ${ }^{11}$ como principal fonte das discriminações e injustiças por ele sofridas. Condição de não nacional que frisa o estado de não sujeito ou sujeito mínimo, dotado de direitos mínimos, no limite do não humano; apenas o necessário para garantir a sua sobrevivência imediata, sem dignidade ou expectativas a médio ou longo prazo.

5 KRISTEVA, Julia. Estrangeiros para nós mesmos, p. 12.

6 APPADURAI, Arjun. O medo ao pequeno número. Ensaio sobre a geografia da raiva.

Ibidem, p. 45.

8 PAIVA, Raquel, BARBALHO, Alexandre (orgs.). Comunicação e cultura das minorias.

9 Ibidem, p. 13.

${ }^{10}$ SOARES, Guido Fernando S. Os direitos humanos e a proteção dos estrangeiros, p. 170.

11 SAYAD, Abdelmalek. Imigração ou os paradoxos da alteridade. 
“Um imigrante só tem razão de ser no modo do provisório e com a condição de que se conforme ao que se espera dele"12. As consequências desse estado, todavia, não se limitam ao campo político administrativo; pelo contrário. Trata-se, na verdade, de um longo trabalho de despojo do sujeito migrante de sua própria humanidade, subjetividade e direito à dignidade que se dá de modo gradativo e através de uma complexa engrenagem retórica e simbólica.

Mezzadra $^{13}$, por sua vez, considera as migrações enquanto movimento social global que não pode ser dissociado do conjunto de movimentos sociais que ocorrem pelo planeta. Radicalizando a dimensão autonomista da multidão, ele refuta as abordagens vitimizantes da figura do migrante; antes, ele adota o princípio de produção de subjetividade no capitalismo como perspectiva metodológica e conceitual. Assim, paralelamente aos dispositivos de dominação e exploração da nossa fase do capitalismo, novas práticas de emancipação e igualdade são experimentadas.

O próprio princípio de cidadania, entendido pelas abordagens clássicas enquanto estatuto jurídico formal, é reinterpretado na perspectiva autonomista a partir de seus atributos combativos. A mobilização social, política e cultural dos migrantes é considerada, em si, como uma ação cidadã concreta e prática, fundada no supremo "direito de reivindicar direitos"14. Ação que acaba transformando, na prática, as noções de democracia e cidadania, e transbordando os limites do Estado-nação, para se inscrever na tradição humanista que não dissocia o ideal democrático dos direitos humanos universais.

Além da vulnerabilidade jurídico-social, já exposta, Sodré ${ }^{15}$ qualifica os grupos minoritários pela sua identidade incompleta ou não reconhecida, a obrigação de travar lutas contra-hegemônicas e a necessidade de se organizar discursivamente para negociar seus status social político e simbólico. Luta e organização que se dão, hoje, principalmente nos espaços midiáticos, em torno e em função dos meios de comunicação. O que nos leva à questão da comunidade e da comunicação comunitária - de modo geral e no caso específico das migrações transnacionais.

\section{Comunidades transnacionais}

No Brasil, duas autoras em especial têm trazido valiosas contribuições ao debate em torno da questão comunitária. Para Peruzzo ${ }^{16}$, os grupos sociais humanos precisam, para serem definidos enquanto comunidades, preencher alguns requisitos de ordem objetiva e subjetiva, tais como a existência, no

\footnotetext{
12 Ibidem, p. 55.

${ }^{13}$ MEZZADRA, Sandro. Multidão e Migrações: a autonomia dos migrantes.

14 Ibidem, p. 28.

15 SODRÉ, Muniz. Prefácio.

${ }^{16}$ PERUZZO, Cicilia et alii (orgs.). Comunicación y movimientos populares: ¿cuales redes?
} 
seu âmbito, de uma cultura comum; sentimento de pertencimento; objetivos comuns, identidade natural e espontânea entre os interesses dos seus membros; relações e interações significativas; a participação ativa na vida da comunidade; uma língua comum; um território comum, etc. ${ }^{17}$

Já Paiva ${ }^{18}$, apreende a comunidade enquanto instrumento de transformação social e de autonomização dos grupos minoritários ou marginalizados. Ao mesmo tempo em que considera a comunidade, na sua forma original e tradicional, incompatível com os regimes de consumismo e individualismo que predominam em nossa época, Paiva enfatiza a sua pregnância semiótica mobilizadora. Meio de resgate da cidadania, a comunidade precisa, antes, se reinventar para se adequar ao quadro social e político atual; notadamente através de sua ação comunicativa, indissociável da própria organização comunitária.

$\mathrm{Na}$ verdade, comunidade e comunicação remetem à mesma raiz etimológica e apontam para o mesmo horizonte filosófico. Comunicar, formar uma comunidade ou entrar em comunhão implicam no mesmo gesto existencial de troca, partilha, participação, contribuição, aproximação e vinculação. Uma comunidade é, portanto, uma comunidade de sentidos, o lugar (físico/territorial ou simbólico/imaginário) onde é produzido, veiculado e compartilhado o sentido comum ao corpo do grupo na sua totalidade reflexiva. Se a comunicação é um processo de produção de sentido, a comunidade é o locus em que esse sentido é construído, transmitido, trocado, codificado e decodificado.

Assim, há de lembrar que, dentre as principais atribuições de natureza social e política intrínsecas à comunicação comunitária está, em primeiro lugar, o seu caráter discursivo responsável pela enunciação e manutenção da identidade do grupo ao qual pertence. No entanto, o discurso (identitário, político e social) que atravessa os meios de comunicação comunitários não é destinado exclusivamente às estruturas organizacionais do grupo, nem é recebido apenas por seus membros.

Pelo contrário, as instâncias sociais e políticas extracomunitárias são igualmente alvo da mídia comunitária. Não há dúvida, pois, que um dos principais objetivos da comunicação comunitária é permitir aos membros da comunidade de se expressarem e participarem dos debates políticos que ocorrem dentro da esfera pública, no afã de fazer ouvir as suas vozes e fazer valer seus pontos de vista.

No caso específico das comunidades migrantes, o espaço migratório não pode ser reduzido à sua dimensão física tradicional. O espaço migratório se destaca, antes, pela multiplicidade dos modos de sua 'produção' social e simbólica ${ }^{19}$ e a natureza intrinsecamente multiterritorial tanto da sociabilidade como da subjetividade do migrante.

\footnotetext{
17 Ibidem.

18 PAIVA, Raquel. O Espírito Comum: comunidade, mídia e globalismo.

${ }^{19}$ LEFEBVRE, Henri. La production de l'espace.
} 
Territórios que podem ser tanto reais e materiais como também ou apenas subjetivos, imaginários e existenciais ${ }^{20}$, produzidos a partir dos processos e dispositivos de enunciação da identidade coletiva do grupo ou comunidade. $\mathrm{O}$ que significa, em primeiro lugar, que a cartografia deste espaço não corresponde fielmente a um determinado 'espaço social nacional', nem pode se restringir a seus recortes estatais nacionais conhecidos e/ou suas instâncias políticoadministrativamente reconhecidas.

Dois conceitos são centrais para essa discussão: transnacionalismo e diáspora. Em que diz respeito ao primeiro, conforme já desenvolvido em estudos anteriores, acreditamos que a ideia de transnacionalismo deve ser examinada à luz das recentes transformações históricas responsáveis pela reconfiguração do conjunto das paisagens sociopolíticas da nossa época.

Nossa definição do conceito remete aos modos de organização e ação das comunidades humanas inseridas em mais de um quadro social nacional estatal, tendo referenciais culturais, territoriais e/ou linguísticos originais comuns, e conectadas através de redes sociais transnacionais que garantem algum grau de solidariedade ou identificação além das fronteiras formais de seus respectivos países de destino. Trata-se, portanto, de um fenômeno 'pós-estado-nacional' inerente à realidade social e política que caracteriza o mundo contemporâneo, sendo a diversidade cultural e identitária, os pluripertencimentos, a multiterritorialidade e as formações diaspóricas cada vez mais a norma ${ }^{21}$.

A característica mais importante desse quadro acima descrito é, todavia, a centralidade dos processos e tecnologias de comunicação na sua ordenação; efetivando modalidades culturais e modos de enunciação identitários propriamente transnacionais. Com o barateamento e a popularização das tecnologias de comunicação e, ao mesmo tempo, a sua sofisticação, ampliação de seu campo de ação, aumento de sua acessibilidade, banalização de seu manuseio e sua definitiva universalização, se pode notar que a maioria das comunidades diaspóricas espalhadas pelo mundo dispõem de um impressionante arsenal de meios de comunicação comunitária - tanto local como transnacional.

Com relação ao segundo conceito, vale lembrar que se, originalmente, a noção de 'diáspora' remetia à 'dispersão dos judeus ao longo dos séculos', hoje, seu uso é admitido para traduzir a realidade social, cultural e política de "qualquer pessoa ou população étnica que abandona a pátria tradicional da sua etnia, estando dispersa por outras partes do mundo"22. No entanto, com o aumento do poder da internet, no fim dos anos 1990, a questão da diáspora

\footnotetext{
${ }^{20}$ GUATTARI, FÉLIX. Caosmose: um novo paradigma estético. São Paulo: Ed. 34, 1992.

${ }^{21}$ ELHAJJI, Mohammed. Les radios communautaires à l'ère des nouvelles technologies: de l'impératif de se réinventer pour perdurer.

${ }^{22}$ OIM. Glossário sobre migração, p. 18.
} 
desencadeou o desenvolvimento de uma ampla literatura cada vez mais voltada para as relações tecidas pelas comunidades de migrantes através das TICs. O que vai acabar configurando, ao longo da década, o conceito de 'webdiáspora'.

Hoje, aceitam-se como sinônimos de 'webdiáspora', noções como 'e-diáspora', 'web diaspórica', 'diáspora networks', 'diáspora digital', entre outras. Entretanto, pondera Claire Scopsi, que "a publicação de sites por membros de uma comunidade transnacional não pode ser vista como um critério único de classificação de webdiáspora, (...) critérios de coesão e reivindicação identitária nos ajudam a sair desse ciclo vicioso"23.

A webdiáspora, segundo ela, além de se referir claramente a sites ou outros formatos internéticos produzidos por membros da diáspora fora do país de origem, deve remeter a um modelo de organização social virtual em torno de elementos culturais compartilhados pela comunidade em sua dimensão transnacional, no afã de reforçar o sentimento de pertencimento identitário de seus membros e subtender suas ações reivindicativas. Em termos práticos, se pode definir a webdiáspora a partir da reapropriação das TICs pelos imigrantes e os usos sociais e subjetivos delas decorrentes; ao exemplo da experiência das webrádios aqui exposta.

\section{Ondas comunitárias}

Não há dúvida que a década de 1980 é a que marca a redemocratização no Brasil. Depois de mais de 20 anos de ditadura militar, a luta pela volta de eleições diretas e o processo constituinte foram importantes para o fortalecimento da sociedade civil brasileira, devido, em grande parte, ao protagonismo da comunicação popular e à consolidação de um movimento nacional e internacional de organização e apoio à luta das rádios comunitárias.

É que a maioria dos países - inclusive o Brasil - não previa em suas legislações qualquer reserva de espectro para a radiodifusão não comercial ou não estatal de baixa potência. Com isso, iniciou-se um processo - ainda em curso - de fechamento sistemático de rádios sem outorga, muitas vezes com truculência policial e violação de direitos civis.

No Brasil, esse movimento culminou na legalização das rádios comunitárias em fevereiro de 1998, em meio a um governo neoliberal e fruto de um Congresso zeloso pelo tema: dos parlamentares membros da Comissão de Comunicação, Tecnologia e Informática, responsável pela aprovação do projeto de lei que regulamentaria a radiodifusão comunitária no Brasil, 70\% eram donos ou tinham interesses indiretos em empresas de rádio e televisão ${ }^{24}$.

\footnotetext{
${ }^{23}$ SCOPISI, Claire. Les sites web diasporiques: un nouveau genre médiatique?, p. 91.

${ }^{24}$ COSTA, Mauro Sá Rego, HERMANN JUNIOR, Wallace. Rádios Livres, rádios comunitárias, outras formas de fazer rádio e política.
} 
O resultado foi uma lei que limita o pleno desenvolvimento das comunitárias legalizadas, hoje $4.641^{25}$ em todo o país. Um estudo nosso ${ }^{26}$ demonstra que, dentre todos os países da América do Sul, o Brasil tem a lei mais restritiva de radiodifusão comunitária no que concerne: definição legal das rádios comunitárias, potência e alcance de transmissão, reserva de espectro, possibilidades de sustentabilidade e prazo de outorga.

Um elemento importante para a presente análise é o próprio entendimento de rádio comunitária na legislação brasileira: ao estabelecer logo em seu primeiro artigo que o funcionamento da emissora está restrito "ao atendimento de determinada comunidade de um bairro e/ou vila", a lei atende somente comunidades geográficas excluindo as chamadas comunidades de interesse, reconhecida em leis congêneres de países vizinhos como Argentina, Equador e Uruguai. Tal restrição é reforçada com a potência de transmissão limitada a 25 watts de potência e em FM (modulação típica para transmissões locais).

Com isso, no Brasil, comunidades etnolinguísticas e migrantes que não se conformam em comunidades geográficas ficam impedidas de constituir meios eletrônicos próprios de comunicação. De acordo com os princípios de universalidade de meios e sujeitos estabelecidos no Sistema Interamericano de Direitos Humanos para o exercício do direito à liberdade de expressão, tais limitações configuram uma violação de direitos em que setores sociais estão privados de aceder a todos os meios possíveis de expressão e informação.

Além disso, a elevada burocracia e a ineficiência do Estado em conceder outorgas arrastam muitas rádios comunitárias para a ilegalidade. De acordo com os dados levantados pela ONG 'Artigo 19' relativos a 2011, durante um período de quatro anos, o Ministério das Comunicações acumulou 11.842 processos pendentes para análise, dando conta de somente 30\% dos casos (5.322 de um total de 17.164$)^{27}$. Com isso, a espera pela outorga pode chegar a 10 anos. A outra face desse processo é o fechamento permanente de rádios sem outorga e condenação de seus comunicadores populares, cifra que ultrapassa sistematicamente o número de concessões ${ }^{28}$.

Porém, sob ausências legais, leis restritivas ou favoráveis, em todo o mundo, as rádios comunitárias seguem relevantes na luta pelos direitos humanos, em geral, e pelo direito à comunicação, em particular. Além do mais, inauguram um novo capítulo, ao acompanharem a tendência geral de hibridização, digitalização e convergência midiática.

\footnotetext{
${ }^{25}$ Dados obtidos no site do Ministério das Comunicações, última atualização em 30.09.2014.

${ }^{26}$ MALERBA, João Paulo. Rádios comunitárias: panorama da situação legal na América Sul.

${ }^{27}$ Artigo 19, Associação Mundial de Rádios Comunitárias - Amarc Brasil, Movimento Nacional de Rádios Comunitárias. Situação das rádios comunitárias no Brasil.

${ }^{28}$ Cf. ibidem.
} 


\section{Do hertz aos bits}

Com a digitalização e a irreversível tendência de hibridação e convergência midiática, aquele que é considerado o primeiro meio eletrônico de comunicação verdadeiramente massivo passa hoje por um interessante (novo) processo de reinvenção de suas técnicas e ampliação de suas potencialidades.

Para permanecer relevante e inovador, o rádio vai incorporando técnicas, adapta sua linguagem e inaugura possibilidades no diálogo com outras mídias. O resultado tem sido a ampliação de sua presença, tornando-se um veículo cada vez mais híbrido. Por conta de espaço e foco, iremos destacar três transformações que afetam mais diretamente as rádios comunitárias (e a própria Comunicação Comunitária): a digitalização do rádio, o surgimento dos podcasts e as webrádios.

O chamado rádio digital faz uso do espectro eletromagnético (da mesma forma que o chamado rádio analógico, o que tradicionalmente conhecemos) para, através de ondas eletromagnéticas, transmitir informação audiofônica (e outras) em sinais digitais (bits). Entre as muitas vantagens dessa tecnologia destacam-se: a possibilidade de melhoria da qualidade do som (rádio FM com qualidade de CD e rádio AM com qualidade de FM); a incorporação de serviços adicionais, como imagens e textos a partir de letreiros digitais nos receptores, com informações como notícias, previsão do tempo e publicidade - o que implica: possibilidades de novos modelos de negócios e maior participação no mercado publicitário; dependendo do modelo e do marco regulatório correspondente, há um uso mais eficiente do espectro, o que poderia favorecer a pluralidade de emissoras, ampliando a participação de rádios comunitárias, educativas, associativas, comerciais etc.; possibilidade de interatividade; menor consumo de energia elétrica; e possibilidade de multiprogramação (mais de uma estação transmitindo na mesma frequência do dial).

Mas o que parece um mar de vantagens esconde custos, disputas políticas, comerciais e industriais, além da difícil mudança no hábito do receptor. Para adequar-se à digitalização do rádio as emissoras têm de mudar seus equipamentos de transmissão. Da mesma forma, para escutar uma emissão de rádio digital é necessário ter um aparelho receptor de sinais digitais. Tanto na transmissão quanto na recepção, os custos dependerão muito do modelo que se adote em cada país e também o desenvolvimento da indústria local.

Em 2005, o Brasil iniciou os primeiros testes com dois dos quatro modelos existentes: a escolha está entre o europeu DRM (Digital Radio Mondiale) e o americano HD RadiolIBOC (High Definition Radio/In-Band-On-Channell). Porém, entre idas e vindas, passados 10 anos desde os primeiros testes, até hoje não se encontrou definição.

Para as rádios comunitárias brasileiras, o rádio digital apresenta possibilidades e muitos riscos. Como já foi dito, com o melhor aproveitamento 
do dial, o hoje reduzido espaço para as comunitárias (um canal por região, ou seja, cerca de $2 \%$ do total) poderia ser ampliado sem a desculpa da escassez de espectro. Por outro lado, como afirma Arthur William, membro da Associação Mundial de Rádios Comunitárias (AMARC Brasil) e integrante do Conselho Consultivo do Rádio Digital, “como não há permissão para publicidade do comércio local e fundo público para financiamento das rádios, as comunitárias não têm condições de se digitalizarem. Os equipamentos de transmissão são caros e, sem mecanismos de sustentabilidade, será impossível uma migração tecnológica para essas estações" ${ }^{\prime 29}$.

Além disso, há incompatibilidade tanto dos testes realizados pelo Ministério das Comunicações quanto nos próprios padrões em disputa com a realidade legal atual das rádios comunitárias. Como foi dito, a Lei 9.612 estabelece 25 Watts de potência: "como no digital a potência é bem menor que a analógica, ruídos urbanos podem gerar um verdadeiro 'apagão' das rádios comunitárias que já operam em muita baixa potência nas transmissões analógicas" ${ }^{\prime 30}$.

Criado em 2004, também chamado de audiocast ${ }^{31}$, o podcast é uma modalidade assincrônica (emissor e receptor não compartilham a simultaneidade da emissão e recepção) de radiodifusão sob demanda, cujo nome resulta da junção da expressão public on demand + casting. Trata-se de programas radiofônicos, de diferentes gêneros (jornalísticos, artísticos, musicais, científicos etc.), normalmente gravados em formato $\mathrm{mp} 3$ para serem facilmente baixados da internet e escutados em mp3 players, celulares ou mesmo no computador à escolha do receptor. O uso é majoritariamente amador, mas mesmo as estações de rádio aderiram, oferecendo em seus sites programas específicos de suas grades em formato de podcast.

Quanto ao nosso tema, é interessante notar podcasts de temática ligada aos direitos humanos profusamente encontrados na rede. Na maioria das vezes, trata-se de iniciativas individuais e pontuais de ativistas (ou seja, iniciativas não comunitárias, na acepção usual do termo), mas não são incomuns rádios comunitárias hertzianas e webrádios comunitárias que já disponibilizam parte da sua programação sob essa modalidade.

Vemos aí interessantes tensionamentos sobre o entendimento clássico de rádio comunitária, ao mesmo tempo em que presenciamos seu dinamismo em acompanhar as inovações tecnológicas com inovações sociais. Tensionamento similar presenciamos numa modalidade de rádio existente desde o início da popularização da internet, em meados da década de 1990: as webrádios.

\footnotetext{
${ }^{29}$ WILLIAM, Arthur. Rádio Digital: padrão será escolhido no Brasil em 2013?

30 Ibidem.

${ }^{31}$ PRADO, Magaly. Audiocast nooradio - redes colaborativas de conhecimento.
} 


\section{Webradiocomunitarismo}

Webrádios, rádios virtuais, e-radio, rádio via internet, rádio online: diferentes denominações para o serviço de transmissão de áudio via internet com a tecnologia streaming gerando áudio em tempo real. Assim como na rádio hertziana, aos ouvintes se apresenta uma programação continuada (sem a possibilidade de pausa ou replay) - o que diferencia a webrádio do podcasting (que envolve download e não streaming). A transmissão é ao vivo, sincrônica, em caráter mundial, mas o sinal das emissoras é transmitido por quaisquer que sejam as formas de conexão à internet.

As primeiras webrádios datam do início da popularização da internet, em meados dos anos 90. Segundo a Associação Brasileira de Emissoras de Rádio e Televisão (Abert), os internautas dispunham, já em setembro de 1997, de 29 rádios virtuais nacionais ${ }^{32}$. Desde então o seu crescimento tem sido exponencial. O que atinge também as rádios comerciais que buscam a abrangência da web: em 2012, 84,1\% das comerciais hertzianas brasileiras já transmitiam seus programas pela internet ${ }^{33}$.

Ainda não temos números atualizados sobre a utilização da webrádio por rádios comunitárias brasileiras ${ }^{34}$. Em $2006^{35}$, realizamos uma pesquisa com 100 emissoras no intuito de aferir o nível de apropriação das novas tecnologias. Naquele momento, verificamos que quase um quarto (23\%) afirmava já transmitir on-line e 67\% declaravam a intenção de fazer tal uso da Internet (somente 5\% acreditavam não haver importância em transmitir via web): ou seja, 90\% das emissoras em questão já transmitiam ou pretendiam transmitir on-line.

Em 2005, Peruzzo realizou uma pesquisa com 94 emissoras que disponibilizavam site na internet ${ }^{36}$. Ao fim da análise, conclui-se que a presença das rádios comunitárias na internet ainda é modesta, sem um "apoderamento total da tecnologia digital, de modo a usufruir todos os recursos que ela oferece ${ }^{\prime \prime 37}$. A pesquisa também revelou que a maioria das emissoras analisadas evidencia

\footnotetext{
${ }^{32}$ KISCHINHEVSKY, Marcelo. O rádio sem onda: convergência digital e novos desafios na radiodifusão, p. 78.

${ }^{33}$ Disponível em: < http://www.telesintese.com.br/sem-padrao-digital-definido-radios-usam-internet -para-sobreviver/>. Acesso em: 19.03.2014.

${ }^{34}$ Esse é um dos objetivos de nossa pesquisa de doutoramento intitulada Rádios comunitárias no limite, que analisa as recentes transformações sociais, políticas e tecnológicas pelas quais têm passado as rádios comunitárias brasileiras, com o apoio do CNPq. Uma pesquisa quantitativa com 100 rádios comunitárias (de diversos tipos) e uma pesquisa qualitativa com 10 emissoras pretendem, entre outros objetivos, averiguar o nível de apropriação tecnológica (e suas inovações técnicas e sociais) desses atores sociais.

${ }^{35}$ Cf. MALERBA, João Paulo. Rádios Comunitárias: ampliando o poder de ação.

${ }^{36}$ PERUZZO, Cicilia. Rádio Comunitária na Internet: apoderamento social das tecnologias, p. 2.

${ }^{37}$ Ibidem, p. 14.
} 
fortes laços comunitários com suas localidades de origem, apesar de os maiores beneficiários de tal apropriação serem os próprios realizadores de tais iniciativas.

A entrada tímida, mas promissora das rádios comunitárias no mundo virtual se figura como uma ampliação da cidadania através do exercício do direito humano à comunicação e inaugura mais uma alternativa de as rádios comunitárias driblarem restrições legais através das possibilidades tecnológicas contemporâneas.

Num primeiro momento, apesar de tecnicamente simples, manter uma webrádio no ar era algo caro: é preciso pagar uma taxa mensal a um servidor de streaming dedicado, cujo valor depende da qualidade de transmissão e da quantidade de ouvintes simultâneos. Normalmente a emissora estabelece um teto máximo e, passado esse número, o ouvinte seguinte não consegue acessar a webrádio. Mas vale destacar que esse valor caiu expressivamente nos últimos anos, como também existem vários projetos de apoio a esse tipo de iniciativa que, no intuito de democratizar os meios alternativos de comunicação, fornecem recurso gratuitos de 'servidor dedicado' ${ }^{38}$

Quanto às suas características, a webrádio coloca em xeque alguns dos pressupostos clássicos do veículo rádio: 1) Trata-se de um meio essencialmente desterritorializado e não massivo: o webrádio tem, potencialmente, audiência mundial e seu público tende a atender mais a uma comunidade de interesse que a uma comunidade geográfica; 2) atende um público bastante segmentado; 3) ampliação da interatividade; 4) convergência midiática; 5) permite a recepção a partir de qualquer parte do mundo, o que pode beneficiar diretamente populações migrantes ou demais comunidades de interesse fisicamente dispersas; 6) desregulamentação: enquanto que para realizar legalmente o serviço de radiodifusão sonora é necessário obter uma concessão do Estado, qualquer pessoa pode ter uma rádio pela internet, sem burocracia ou constrangimento legal. Há, como se pode observar, um eminente potencial democratizante na webrádio.

A webrádio se apresenta como uma alternativa viável para uma série de atores sociais que se sentem excluídos do cenário midiático e que encontram dificuldades para acessar legalmente as outorgas de radiodifusão - como é o caso dos imigrantes. De fato, as atuais restrições da Lei brasileira de radiodifusão comunitária dificultam seu acesso especialmente por comunidades de natureza diaspórica:

1) Lei vinculada à comunidade territorial. Como foi tratado no tópico 4 , o serviço de radiodifusão comunitária no Brasil está direcionado para comunidades

${ }_{38}$ É o caso do Projeto Dissonante (<http://www.dissonante.org $>$ ), uma iniciativa de estudantes e entusiastas do rádio livre da Universidade de Brasília. Surgido em 2007, trata-se de um braço de ação do Programa de Extensão Comunicação Comunitária (FAC/UnB) ainda que gerido por um coletivo que atua de forma colaborativa e voluntária. Tem como foco facilitar que rádios comunitárias, organizações sociais, grupos de ativistas etc., ou seja, coletivos acedam ao serviço de webradiodifusão. 
geográficas, o que se reforça com a limitação de 25 watts de potência e transmissão exclusivamente em FM. Isso exclui uma série de atores coletivos, como migrantes e demais comunidades de interesse que se organizam para além do território;

2) Impossibilidade de estrangeiros acederem ao espectro eletromagnético. Somente "brasileiros natos ou naturalizados há mais de dez anos" podem ser dirigentes de rádios comunitárias. Retomando a discussão empreendida no tópico 2, sob a pretensa proteção dos interesses nacionais, tal limitação acaba por avigorar o estatuto social e político de subalternidade do migrante;

3) Obrigatoriedade do Português nas emissoras. Existem previsões sobre a veiculação de conteúdos em português nas concessões de radiodifusão (Norma de Acessibilidade e alguns contratos para a prestação do serviço entre emissoras e União), o que virtualmente impede comunidades migrantes de acederem integralmente sua língua originária nas ondas hertzianas. Há aqui toda uma discussão sobre a artificialidade da ideia de nação, reforçada pela língua;

4) Restrições de financiamento. As rádios comunitárias estão impedidas de realizar qualquer tipo de publicidade comercial, mesmo que seu retorno seja para a própria emissora (tendo em vista que, por princípio, são entidades sem fins de lucro), apenas podendo aceder apoio cultural e doações. Ora, isso atinge o calcanhar de Aquiles das comunitárias, normalmente direcionadas a grupos social, política e economicamente desfavorecidos. No caso de comunidades migrantes vemos a dificuldades de autofinanciamento para um grupo, na maioria das vezes, estigmatizado e com carências econômicas.

\section{Considerações finais}

Assim, tanto no âmbito acadêmico quanto associativo e da sociedade civil em geral, vislumbram-se desafios inéditos para a área de estudo da comunicação comunitária e para a própria luta pelo direito humano à comunicação. Direito que se no contexto comunitário como todo, constitui um dos elementos centrais para a organização da coletividade enquanto unidade social, no caso específico das comunidades migrantes e diaspóricas, tal prática adquire importância e valor vitais para a sobrevivência e prosperidade do grupo em suas dimensões identitárias, culturais, sociais e políticas.

Todavia, a guinada internética aqui abordada é passível de múltiplas leituras e análises. Primeiro, no plano teórico, há de se atentar ao fato de que, conforme já assinalado, o caráter virtual das webrádios coloca em xeque toda a literatura consensual sobre a suposta primazia do elemento espacial e territorial enquanto condição sine qua non para a existência e sobrevivência das comunidades e o sucesso de seus sistemas de comunicação. Ao mesmo tempo em que se tem que reconhecer que esse estatuto 'a-espacial' ou 'supralocal' do novo médium 
(suporte e linguagem confundidos) corresponde melhor à natureza diaspórica, transnacional e multiterritorial das comunidades migrantes.

Sem esquecer que a virtualização das rádios comunitárias permite driblar as restrições impostas às rádios hertzianas, as dificuldades abusivas de ordem burocrática para a obtenção do direito de emitir e as incertezas do futuro da radiofonia digital no Brasil. A webradiofonia permite às comunidades migrantes romper as limitações físicas e técnicas que impedem o alcance necessário para seus membros geograficamente dispersos, no afã de conectá-los e sincronizar a sua atenção coletiva em torno dos mesmos discursos sociais, culturais e políticos. O que viabiliza uma maior mobilização dessas comunidades, tanto no plano local como transnacional, para a conquista de direitos sociais e políticos e, numa perspectiva mais ampla e mais longa, a efetivação da tão sonhada cidadania universal.

Por outro lado, observa-se que, muitas vezes, as webrádios comunitárias, sejam elas diaspóricas ou não, são o fruto de iniciativas pessoais de indivíduos ou grupos isolados, e não, como é geralmente o caso nas rádios comunitárias tradicionais, a consequência de decisões institucionais tomadas por instâncias legais e juridicamente representativas. Fato que, a nosso ver, não deve ser interpretado enquanto indicador de declínio ou enfraquecimento do espírito comunitário, mas sim como reflexo do potencial de autonomização (empowerment) política e social do sujeito comunicante inserido no atual ambiente tecnológico, marcadamente rizomático e distribuído em rede ou rede de redes. Para os estudos de comunicação comunitária apresenta-se o desafio de dar conta de objetos novos ao escopo inicial de seus estudos: manter a perspectiva crítica, mas aberta para iniciativas pontuais e inovadoras, porém de viés cidadão. Para tal, vemos a necessidade de buscar novos e renovar antigos marcos conceituais para dar conta desse novo ambiente.

É preciso, ainda, reconhecer que a própria prática midiática e comunicativa relativa ao atual contexto tecnossocial não parece priorizar as funções sobre as funcionalidades, mas sim optar por estratégias plurais e híbridas, nas quais o suporte se dilui na finalidade comunicativa e social ${ }^{39}$. Assim, muitos dos migrantes, entrevistados em investigações empíricas realizadas pelo grupo de pesquisa 'diaspotics.org', deixam claro que todos os aplicativos dos quais eles dispõem são usados quase que paralelamente, dependendo da tendência do momento, da disponibilidade ou da escolha da maioria da comunidade.

As tecnologias não seriam adotadas de modo singular e isolado, mas sim apropriadas enquanto parte de uma ecologia cognitiva maior, constituída pelo conjunto das redes sociais e a 'tecnosfera' que as engloba. Ou seja, os imigrantes fazem usos comunitários de toda uma gama de aplicações e recursos midiáticos disponíveis na rede - mesmo que a finalidade inicial desses não tenha vocação

${ }^{39}$ ELHAJJI, Les radios communautaires..., op. cit. 
comunitária. Assim, tanto a produção midiática propriamente comunitária do grupo (blogs, páginas pessoais, perfis no Facebook, grupos no Whatsapp, Skype, Viber, etc....) como a mídia do país de origem (imprensa, rádios e TV) disponível online e a mídia comunitária das 'comunidades irmãs' espalhadas pelo mundo acabam constituindo um mesmo continuum conteudístico ético e estético em contínua circulação e reinterpretação entre os membros da comunidade.

A essa diversidade dos usos e reapropriações das tecnologias de comunicação pelo público migrante corresponde uma notável pluralidade dos modos de organização, apresentação e funcionamento das webrádios - devido à mutabilidade desses meios e sua predisposição à experimentação e inovação. $\mathrm{Na}$ verdade, conforme constatamos em nossa pesquisa em curso, não é fácil isolar a atividade webradiofônica do conjunto das ações internéticas empreitadas pelos imigrantes e comunidades diaspóricas em seu trabalho de construção de uma identidade cultural e política local/transnacional. Todavia, acreditamos que seja interessante concluir esse nosso percurso analítico com alguns exemplos de webrádios pelo mundo; não no sentido de exaurir a totalidade de possibilidades oferecidas pelas TICs nesse registro ou de definir algum padrão normativo, mas, antes, ilustrar a pluralidade acima referida.

Um desses exemplos é o da webrádio 'Migrantes' (http://www2.redesul. am.br/rsradios/índex.php). Voltada para o "brasileiro e que está morando fora de sua querida Pátria", a webrádio pertence ao Centro Scalabrino de Comunicação, do Seminário São Carlos na cidade de Guaporé (RS) e faz parte da Rede Sul de Rádio, que engloba uma dezena de emissoras do interior do Rio Grande do Sul. Ainda que institucionalmente vinculado a uma organização religiosa e sem abertura formal à participação direta de membros da comunidade, tal espaço virtual tem servido como canal de informação para migrantes, a partir de uma perspectiva social, cultural e de direitos. Sua gênese católica remete à origem de muitas das rádios comunitárias latino-americanas, surgidas a partir de iniciativas de uma ala mais progressista da Igreja e gradativamente apropriadas por suas comunidades para fins de mobilização social e luta pela cidadania.

A rádio, inaugurada em 2009, é presente em diversas plataformas tais como a página do Centro Scalabrino, redes católicas, sites parceiros e Facebook. Além de sua programação diária em português e espanhol, a webrádio também disponibiliza banco de imagens, agenda de eventos e programas informativos em podcast. Seu conteúdo, tanto sonoro como imagético e textual, é voltado para os direitos políticos e sociais dos migrantes, os direitos humanos em geral, a defesa do meio ambiente e o reforço da identidade brasileira - conforme informa a própria página da rádio.

A 'Voz do Haiti', nosso segundo exemplo, interessa justamente pelo fato de não ser exatamente uma webrádio, mas, antes, um programa de rádio voltado 
para a comunidade haitiana recém estabelecida no Brasil. Produto de uma parceria com a ONG 'Viva Rio', o programa integra a grade da 'Rádio Viva Rio' - trazendo, num estilo dinâmico, interativo e multilíngue, "informação, cultura, música, tecnologia e as últimas notícias do país caribenho". Motivo pelo qual o caso nos parece uma boa ilustração de nossa premissa relativa à 'diluição' da webradiofonia num quadro maior de plataformas e aplicativos, onde as funções precedem as funcionalidades.

Assim, o mais importante dessa experiência é a articulação do 'Voz do Haiti' com o conjunto de ações promovidas pela entidade através do site 'Haiti Aqui' (http://haitiaqui.com/br/), cuja missão principal é "facilitar a integração dos imigrantes haitianos à sociedade brasileira", oferecendo "informações sobre processos administrativos, oportunidades de empregos, cursos de capacitação, mapa com endereços úteis para o imigrantes e atendimento online". Fica evidente, portanto, a natureza local e comunitária da iniciativa, na medida em que busca efetivar um espaço de identificação, reconhecimento e autonomização dos imigrantes haitianos - não em separado, mas juntamente com a sociedade civil carioca.

Já nosso terceiro caso, 'Allo Dakar' (http://www.allodakar.com/), representa um modelo composto que foca tanto a vida social, cultural e política no Senegal como assuntos de interesse da diáspora senegalesa pelo mundo. Paralelamente à parte textual do site, organizada em editorias e seções, 'Allo Dakar' oferece a programação de sua rádio ao vivo, programas de áudio em podcast e a webrádio 'Banc Diakhlé Immigrés Yi' voltada principalmente para os emigrados senegaleses.

A página, que também contém links de várias webrádios de comunidades senegalesas em diversas localidades pelo mundo, é um exemplo desse consumo híbrido das mídias internética pelo público. Os imigrantes senegaleses, por nós entrevistados, deixaram claro que este uso não primava pela fidelidade ou exclusividade, mas dependia da oportunidade e do meio disponível.

Por fim, nosso último exemplo pode ser considerado uma das raras e mais antigas webrádios multicomunitárias, multiculturais / interculturais, multiétnicas e multilíngues do mundo. Antes de se espelhar na web no final dos anos 90, a 'Rádio Centre-Ville' (RCV) já era, desde 1972, uma das primeiras rádios multicomunitárias do Canadá e a primeira e ainda única da parte francófona do país norte-americano. 'RCV' (http://radiocentreville.com/) emite em oito línguas: inglês, espanhol, grego, creole haitiano, mandarim, cantonês, português e francês; sendo esse último idioma usado na programação de muitas das comunidades étnicas tanto francófonas como 'alófonas' de Montreal.

Apoiada por mais de 350 voluntários e financiada benevolamente por organismos associativos, a rádio voltada em primeiro lugar para as comunidades de migrantes residentes de Montreal, se propõe como missão a promoção da "livre circulação das ideias, dando voz aos sem voz e aos esquecidos da mídia de 
massa", no afã de enriquecer a vida social e cultural de Montreal, contribuir para o diálogo entre as comunidades que compõem o mosaico migratório da cidade e sua integração social e cultural, e lutar contra todas as formas de discriminação e injustiça social. Seu grande trunfo é conseguir juntar todas as comunidades de imigrantes no mesmo espaço virtual e radiofônico, permitindo uma sinergia criativa e cidadã, não apenas formalmente multicultural, mas verdadeiramente intercultural.

Eis alguns exemplos da flexibilidade, dinamismo e vivacidade do mundo webradiofônico e, principalmente, sua absoluta adequação ao modo de organização e comunicação das comunidades migrantes e diaspóricas. Porém, em conclusão do presente estudo, não podemos deixar de relativizar os benefícios das novas tecnologias tanto para os comunicadores populares das rádios comunitárias quanto para suas comunidades alvo.

No caso das webrádios, conforme aponta Lawrie Hallet ${ }^{40}$, a sua universalização continua longe de se tornar uma realidade para todos, tendo em vista o alto custo de acesso das webrádios pelo celular, a insuficiência da largura da banda e as limitações técnicas em geral nas regióes periféricas - destino natural das comunidades migrantes ainda em situação econômica e social precária. Janey Gordon ${ }^{41}$, outra estudiosa das rádios comunitárias, alertou, em entrevista aos autores, sobre alguns desses empecilhos, tais como a restrição de audiência (quanto maior o sucesso da webrádio, mais cara fica sua manutenção) e os gastos com direitos autorais. Sua principal preocupação, todavia, diz respeito à questão de segurança tanto dos comunicadores como dos ouvintes e usuários, já que a difusão online permite não apenas saber o número exato de ouvintes em tempo real, mas, pior ainda, localizar cada ouvinte através do dispositivo usado para acessar a webrádio. Em tempos de intolerância galopante e crescente desconfiança para com os estrangeiros, a apreensão é mais do que justificada.

\section{Bibliografia}

APPADURAI, Arjun. O medo ao pequeno número. Ensaio sobre a geografia da raiva. São Paulo: Illuminuras: Itaú Cultural, 2009.

ARTIGO 19; Associação Mundial de Rádios Comunitárias - Amarc Brasil; Movimento Nacional de Rádios Comunitárias. Situação das rádios comunitárias no Brasil. Documento apresentado à Audiência Temática na Corte Interamericana de Direitos Humanos - OEA, 11 de março de 2013, Washington, EUA. Disponível em: $<$ http://artigo19.org/wp-content/uploads/2013/03/CIDH-RadCom-Documentofinal-3.pdf > . Acesso em: 06.03.2015.

COSTA, Mauro Sá Rego; HERMANN JUNIOR, Wallace. Rádios Livres, rádios comunitárias, outras formas de fazer rádio e política. Revista Lugar Comum, Rio de Janeiro, n. 17, Mai - Out, 2002, p. 97-107.

${ }^{40}$ HALLET, Lawrie. How 'New Technologies' impact Community Radio.

${ }^{41}$ GORDON, Janey (ed.). Community Radio in the Twenty-First Century. 
ELHAJJI, Mohammed. Mapas subjetivos de um mundo em movimento: migrações, mídia étnica e identidades transnacionais. In MAIA, João; HELAL, Carla (orgs.). Comunicação, arte e cultura na cidade do Rio de Janeiro. Rio de Janeiro: UERJ, 2012, p. 215-238.

ELHAJJI, Mohammed. Les radios communautaires à l'ère des nouvelles technologies: de l'impératif e se réinventer pour perdurer. Les Enjeux de l'information et de la communication, n. 14, 2013, p. 73-83.

GORDON, Janey (ed.). Community Radio in the Twenty-First Century. London: Peter Lang, 2012.

HALLET, Lawrie. How 'New Technologies' impact Community Radio. In OLIVEIRA, Madalena; PORTELA, Pedro; SANTOS, Luís Antônio (eds.). Radio Evolution: Conference Proceedings. Braga. Universidade do Minho, 2011, p. 39-47.

KISCHINHEVSKY, Marcelo. O rádio sem onda: convergência digital e novos desafios na radiodifusão. Rio de Janeiro: E-Papers Serviços Editoriais, 2007.

KRISTEVA, Julia. Estrangeiros para nós mesmos. Rio de Janeiro: Rocco, 1994.

LEFEBVRE, Henri. La production de l'espace. Paris: Ed anthropos, 1974.

MALERBA, João Paulo. Rádios Comunitárias: ampliando o poder de ação. Rio de Janeiro: Monografia de final de curso em Comunicação Social - ECO/UFRJ, 2006.

MALERBA, João Paulo C.; BROCK, Nils. Um ar mais livre? Uma breve abordagem comparativa da situação legal das rádios comunitárias na Europa e América do Sul. 2013 (Apresentação de Trabalho/Conferência ou palestra).

MALERBA, João Paulo. Rádios comunitárias: panorama da situação legal na América Sul. Observatório da Imprensa, edição 712 de 17/09/2012. Disponível em: <http://www.observatoriodaimprensa.com.br/news/view/_ed712_panorama_da_ situacao_legal_na_america_sul>.Acesso em: 19.7.2014.

MEZZADRA, Sandro. Multidão e Migrações: a autonomia dos migrantes. Eco-pós, Revista do Programa de Pós-gradução da escola de comunicação da UFRJ, v. 15, n. $2,2012$.

OIM. Glossário sobre migração. Genebra: Organização Internacional para as Migrações, 2009.

PAIVA, Raquel. O Espírito Comum: comunidade, mídia e globalismo. Petrópolis: Vozes, 2003.

PAIVA, Raquel; BARBALHO, Alexandre (orgs.). Comunicação e cultura das minorias. São Paulo: Paulus, 2005.

PERUZZO, Cicilia et alii (orgs.). Comunicación y movimientos populares: ¿cuales redes? São Leolpoldo: UNISINOS, 2002.

PERUZZO, Cicilia. Rádio Comunitária na Internet: apoderamento social das tecnologias. In Congresso Brasileiro de Ciências da Comunicação, 28, 2005. Rio de Janeiro. Anais... São Paulo: Intercom, 2005. CD-ROM.

PRADO, Magaly. Audiocast nooradio - redes colaborativas de conhecimento. Trabalho apresentado no NP Rádio e Mídias Sonoras do Intercom - VIII Encontro dos Núcleos de Pesquisa em Comunicação, do XXXI Congresso Brasileiro de Ciências da Comunicação, 2008. 
SAYAD, Abdelmalek. Imigração ou os paradoxos da alteridade. São Paulo: Edusp,1998. SCOPISI, Claire. Les sites web diasporiques: un nouveau genre médiatique? In MATTELART, Tristan (org.). TIC \& DIASPORAS. Revista Tic \& Societé, v. 3, n. 1-2, 2009.

SIMMEL, Georg. O estrangeiro. Revista Brasileira de Sociologia da Emoção, 2005. Disponível em: <http://paginas.cchla.ufpb.br/grem/SIMMEL.O\%20estrangeiro. Trad.Koury.rbsedez05.pdf>. Acessado em: 26.08.2015.

SOARES, Guido Fernando S. Os direitos humanos e a proteção dos estrangeiros. Revista de Informação Legislativa, v. 41, n. 162, Brasília: Senado Federal, abr.-jun. 2004.

SODRÉ, Muniz. Prefácio. In PAIVA, Raquel; BARBALHO, Alexandre (orgs.). Comunicação e Cultura das Minorias. São Paulo: Paulus, 2005, v. 1.

WILLIAM, Arthur. Rádio Digital: padrão será escolhido no Brasil em 2013? Disponível em: < http://amarcbrasil.org/radio-digital-padrao-sera-escolhido-no-brasil-em-201 3/>. Acesso em: 07.03.2015.

\section{Abstract}

\section{Comunity uses of webradio in the transnational migratory context}

The migration phenomenon has experiencing, currently, outstanding intensification. Beyond its social, economic and political reasons, there are technological, symbolic and subjective issues influencing it. The will and the need of producing its own narrative in order to help the conservation of its ties with its original and diaspora communities are finding support in innovative media initiatives, clustered under the notion of 'webdiaspora'. Among them, we highlight the webradios of migrant communities object of our study, where we intend to apprehend some of the modes of organization of migrants communities, its strategies for acquiring global citizenship and its actuation in transnational spaces. Through the study of webradios of migrant communities we intend to evidence the potential and weaknesses of webdiaspora to the democratization of communication and the conceptual and theoretical challenges for the community communication studies.

Keywords: transnational migrations, community webradios, community communication, ICTs.

Recebido para publicação em 12.02.2016

Aceito para publicação em 05.04.2016

Received for publication in February 12 $2^{\text {th }}, 2016$

Accepted for publication in April 05 ${ }^{\text {th }}, 2016$

ISSN impresso 1980-8585

ISSN eletrônico 2237-9843

http://dx.doi.org/10.1590/1980-85852503880004608 